\title{
Crowdfunding Industry Development: Gaining Leading Role in Digital Economy and Future Trends
}

\author{
Kateryna Andriushchenko ${ }^{1}$, Mariia Tepliuk ${ }^{1}$, Nataliia Pokotylska ${ }^{2}$, Igor Vinichenko ${ }^{3}$, Oksana Kuchai ${ }^{4}$, Dmytro \\ Mishchenko $^{5} \&$ Yulia Kakhovych $^{6}$ \\ ${ }^{1}$ Department of Economics and Entrepreneurship, Kyiv National Economic University named after Vadym Hetman, \\ Kyiv, Ukraine \\ ${ }^{2}$ Department of Management, Public management and Administration, State Agrarian and Engineering University in \\ Podilia, Kamianets-Podilskyi, Ukraine \\ ${ }^{3}$ Department of the Economic, Faculty of Management and Marketing, Dnipro State Agrarian and Economic \\ University, Dnipro, Ukraine \\ ${ }^{4}$ Department of Tourism and Physical Education, Kyiv National Linguistic University,Kyiv, Ukraine \\ ${ }^{5}$ Department of Marketing, University of Customs and Finance, Dnipro, Ukraine \\ ${ }^{6}$ Management of Foreign Economic Activity Department, University of Customs and Finance, Dnipro, Ukraine \\ Correspondence: Kateryna Andriushchenko, Department of Economics and Entrepreneurship, Kyiv National \\ Economic University named after Vadym Hetman, Kyiv, Ukraine.
}

Received: August 7, 2020

doi:10.5430/rwe.v11n6p311
Accepted: November 5, 2020

Online Published: December 20, 2020

URL: https://doi.org/10.5430/rwe.v11n6p311

\begin{abstract}
In the course of the study, it was found that crowdfunding companies follow a certain stage in their functioning and development: choosing a platform; category selection; the wording of the crowdfunding campaign; definition of a financial goal; determination of the project duration; definition of a reward system; creating a video message; description of the project; regular updates; monitoring the fundraising process. By conducting research on the international market, it was found that with a market size of $\$ 358.28$ billion and a share of $85.99 \%$, China is the largest crowdfunding market in the world. Also, it should be noted the Asia-Pacific region, as Australia took 4th place with funding of $\$ 1.49$ billion, and South Korea - 5th place with $\$ 1.13$ billion, we also find other countries in the Asia-Pacific region in the list of the largest crowdfunding countries in the world. The results of our study concluded that there are many players in crowdfunding in Europe, especially in the field of P2P lending, compared with the Americas and the Asia-Pacific region, as a whole it is a small region. The article also notes the advantages and disadvantages of the crowdfunding development in modern conditions of market functioning.
\end{abstract}

Keywords: crowdfunding, crowdfunding companies, market size, the fourth industrial revolution, digitization

\section{Introduction}

Crowding is a large industry, and its scope is constantly expanding. As a result, we can look a lot of crowdfunding statistics, each telling us a valuable story about running a successful campaign. On average, $\$ 17.2$ billion is generated annually through crowdfunding in North America. And that number is steadily growing - forecasts for the crowdfunding market indicate that it will reach astronomical heights in the next few years. In fact, the cumulative annual growth rate of $14.7 \%$ is projected over the next four years.

Funds raised through crowdfunding increased 33.7\% compared to last year (2018). Approximately, 6,455,080 crowdfunding campaigns were conducted worldwide. Successful crowdfunding campaigns attracted on average $\$ 28,656$. These crowdfunding statistics paint an interesting picture for us - most successful crowdfunding campaigns find a balance between realistic goals and ambitious fundraising strategies, so that number may be smaller than some expect. The average amount collected in all crowdfunding campaigns last year (2018) was \$ 824.

The average success rate of crowdfunding campaigns is $22.4 \%$. Overall, crowdfunding projects have an average of 47 sponsors. This is a solid number of individual donations - generally successful campaigns do not seem to rely on a small number of huge donations, but rather on a moderate number of medium-sized donations. Full-scale 
crowdfunding projects have an average of 300 sponsors. The average pledge for fully funded projects is $\$ 96$.

This crowdfunding statistic helps to support the hypothesis that most successful campaigns are becoming successful with small contributions rather than a small number of huge donations. The average pledge for all crowdfunding projects is $\$ 88$. Here we see that the sample fluctuates. Unlike the average amount of funds raised and the average number of sponsors, the average number of collaterals for successful campaigns is not significantly different compared to all campaigns.

This comparison is further proof that the supporters you reach rather than the patrons, tend to campaign. The crowdfunding market is projected to grow to $\$ 300$ billion by 2030. It is projected that by 2023 there will be 12063 870 campaigns.

Video crowdfunding campaigns earn $105 \%$ more than non-video campaigns. Adding a personal video to your crowdfunding campaign can mean doubling the capital for your project. And you will see even bigger return if you look directly into the camera. Numerous studies have shown that finding potential donors in the eye will mean receiving more promises.

Campaigns that updated subscribers regularly increased $126 \%$ more than those with no updates. In addition, the study results showed that, out of a sample of 8,529 Kickstarter campaigns, the chances of campaign success dropped to $32.6 \%$ if no updates were published, but rose to $58.7 \%$ when the campaign released updates. Updates not only allow you to earn more, but they also determine whether your crowdfunding campaign will reach its goal.

Crowdfunding campaigns that raise at least $30 \%$ of their target within the first week are more likely to reach their target. The initial impulse will not only create a solid financial foundation for your campaign, but also gain access to a wider audience through updates and referrals. As a whole, 53\% of mail campaigns in crowdfunding campaigns are donations.

One of the most effective ways to get people to announce your campaign is to email it. In fact, more than half - 53\% - of email shares in crowdfunding campaigns are in fact donations. On average, $12 \%$ of Facebook shares are converted into donations. Although Facebook is a great way to get information to your entire community, it doesn't necessarily make people click the donate button. About 3\% of Twitter shares are converted into donations. Obviously, tweeting isn't direct enough to make your community feel like supporting your crowdfunding campaign. Although, again, posting on Twitter cannot harm the dissemination of information about your campaign, make sure you have supplemented it with a healthy dose of direct coverage.

All-or-nothing model campaigns are fully funded twice as fast as all-out campaigns. Due to the reduced perceived risk of all-or-nothing campaigns, $34 \%$ of them fully funded their funds, while only $17 \%$ of the all-out campaigns achieved their goal. Knowing that donation fees may not be charged if the campaign does not achieve its goal seems to make potential donors more willing to support the campaign. Adding personal information to your campaign can give you $79 \%$ more patrons.

A psychological study examined the case of donations based on how much personal information potential donors received about the recipient of the campaign funds. The campaign, which offered the name, age and image of the recipient, received 79\% more supporters than the campaign in which the recipient was not identified. Thus, not only personal videos and photos are required, your own background information for backing them up is also crucial.

Approximately $42 \%$ of the funds are raised in the first and last three days of the medium crowdfunding campaign. Thus, not only these first three days will set the stage, but the last three-day push will also round up your campaign. Together, these six days will make up nearly half of your campaign's funds. The average number of words for successful crowdfunding campaigns is between 300 and 500 words. So, avoid looking into the description of your crowdfunding campaign - quickly get to the bottom and make sure that your step is in the first paragraph.

However, make sure that you have all the necessary details, such as the necessary context and logistics for your project. Team crowdfunding campaigns attract $38 \%$ more than single-player campaigns. Teams imply accountability, checks and balances. Thus, a donation to a team-driven project will mean that your promise is likely to be directed exactly at what should be directed.

People aged 24 to 35 are much more likely to participate in crowdfunding campaigns. If you can find potential promoters at this age, you are likely to have a higher conversion rate than campaign administrators who don't communicate with people of that age. Those over 45 are significantly less likely to support campaigns. If your communities are primarily made up of people over 45 , consider how you can reach an age that is more likely to support your campaign. 
Successful crowdfunding campaigns take an average of 11 days to prepare. Be sure to know that this fundraising strategy is by no means an easy prey. Creative planning, a well-thought-out strategy and a significant amount of working time are likely to be needed. The average crowdfunding campaign lasts 9 weeks. A successful campaign administrator publishes an average of 4 times per campaign. Crowdfunding campaign administrators who share less than 2 times have a 97\% chance of failure. On Kickstarter, 319,051 projects were completed - the most common for any platform. Fundrazing projects have a $41.8 \%$ chance of success - the best chance of success on any platform.

\section{Literature Survey}

The theoretical and statistical studies of many scientists became the basis of this study. For the formation of the hypothesis of scientific knowledge at the methodological level, research and scientific publications in the field of crowdfunding are conducted.

Crowdfunding, as an online platform for attracting investment in innovative enterprises, appeared in the early 2010s. Due to the development of startup projects and the development of the venture capital market, the need for crowdfunding research has become urgent (Martínez-Climent et al., 2018).

The main advantage of crowdfunding is the opportunity for innovative companies to seek and protect investments through their platform (online) (Estrin et al., 2018; Horvát et al., 2018).

An innovative company has the opportunity, being in different parts of the world online to apply for participation and attract investment, crowdfunding platforms provide a high level of visibility, in online mode potential investors can see the total amount of already invested funds and the number of investors who have already participated in the campaign (Kim and Viswanathan, 2018).

Despite a fairly large number of published articles on crowdfunding, this area is still in the early stages of study, so you need to focus on the results of related studies. Many early studies were based on venture capital research (Bretschneider et al., 2014; Cholakova and Clarysse, 2015; Löher et al., 2018; Piva an d Rossi-Lamastra, 2018; Venturelli et al., 2018).

The main sources of external financing are business angels, venture capital, and relatively recently crowdfunding (Bapna, 2017; Brown et al., 2018; Drover et al., 2017).

Recently, crowdfunding platforms by business angels and venture capital have been quite frequently and actively used (Baeck et al., 2014; Brown et al., 2018; Wright et al., 2015). In the publication, the authors expressed concern about the use of various forms of financing on the crowdfunding platform in the early stages, which is subject to the market dynamics (Hornuf and Schwienbacher, 2016; Tuomi and Harrison, 2017). While some express concerns about the use of crowdfunding (Vulkan et al., 2016), others find it as a good and effective addition to other forms of attracting investment in innovative companies (Tuomi and Harrison, 2017).

The authors in their work regarding the study of various forms of entrepreneurship financing, support the positioning and legitimization of crowdfunding as one of the elements of the financial and credit infrastructure (Mochkabadi and Volkmann, 2018). According to a survey conducted by Guenther et al. (2014), 4\% of crowdfunding investors are family members or friends of job seekers. In 2018, repeated studies were carried out indicating that $3 \%$ of crowdfunding investors are somehow connected with this company (Guenther et al., 2018).

These studies suggest that entrepreneurs who run crowdfunding campaigns to attract investment seek to create new relationships and expand their sources of raising capital by attracting new investors through the platform (Brown et al., 2018). Do not underestimate the social networks of innovative companies that play an important role in the formation of financing (Lukkarinen et al., 2016; Vismara, 2016)

\section{Methods}

When determining the price of crowdfunding capital, various aspects should be taken into account: both the crowdfunding scheme itself and the crowdfunding model (Fig. 1).

To determine the price of crowdfunding, the size of the financial goal is calculated. A financial goal is the amount of funds that must be collected within a specified period on a crowdfunding platform. It should include:

1) funds necessary for the project implementation;

2) the crowdfunding platform commission;

3) collection of the payment system;

4) tax, as the platform acts as a tax agent. 
That is, on a crowdfunding platform, you need to collect such an number of funds so that after deducting from it a crowdfunding platform commission, collection of the payment system and tax, the amount of funds that are needed directly for the implementation of the project remains:

$$
\mathrm{FG}=\mathrm{FG} * \mathrm{~K} \% / 100-\mathrm{FG} * \Pi \mathrm{C} \% / 100-\mathrm{FG} * \mathrm{H} \% / 100=\mathrm{NF}
$$

From this equality we express the financial goal:

$$
\mathrm{FG}=\mathrm{NF} / 1-[\mathrm{K} \% / 100+\Pi \mathrm{C} \% / 100+* \mathrm{H} \% / 100]
$$

where:

FC - financial goal;

$\mathrm{K} \%$ - percentage of crowdfunding platform commission, \%;

PS\% - payment system collection, \%;

$\mathrm{R} \%$ - the rate of personal income tax or income tax, \%;

$\mathrm{NF}$ - the necessary funds for the implementation of the project.

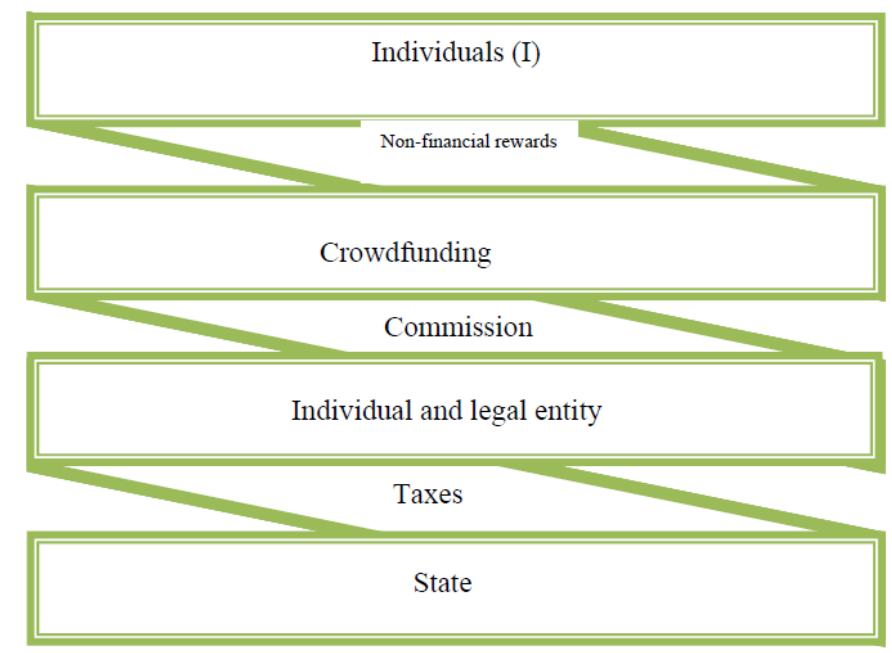

Figure 1. Scheme of organizing crowded financing

Source: formed by authors

All things considered, crowdfunding campaign algorithm, consist with:

1. The choice of platform. When choosing a platform, you should first pay attention to the model and the type by which they work. The further determination of the reward system depends on this, and whether the collected funds will be transferred to the creator of the project when the financial goal is not achieved.

Other selection criteria are what projects the platform targets and whether it is popular on the Internet. It depends on what nature and how much the audience will view your project on the platform (Andriushchenko, Tepliuk et al., 2019). And the last criterion is the monetization of the platform, that is, what percentage of the collected amount will be the commission and collection of the payment system. All of the above criteria should be considered when choosing the optimal platform.

2. Select a category. The choice of category is based on the proposed crowdfunding platform and depends on the nature of the project. If there are doubts about being classified, you can get help from crowdfunding platform managers. The most common categories are: animation, charity, video, design, food, games, art, cinema, literature, fashion, music, science, society, sports, dancing, theater, technology, photography, etc.

3. The wording of the crowdfunding campaign. It is required to formulate the name of the crowdfunding company, reflecting the essence of the project, as well as the purpose of using the collected funds. 
4. Definition of the financial goals. The calculation of the financial goal is given above.

5. Determination of the project duration. Project duration is the time period set by the author of the project during which it is necessary to collect the necessary amount for the project. By increasing the project duration, you will not reduce the risk of a campaign failure. Overblown deadlines demotivate both the author and the audience, and you will need to make more efforts to maintain the project.

6. Definition of a reward system. Develop a detailed reward system with a description, as well as how to receive it. Based on Kickstarter statistics, it was concluded that the optimal minimum reward value is $\$ 100,50,25$, since they make up most of the money collected and are the most popular.

7. Creating a video message. Create a motivating video that represents the essence of the project and its author. Tell him about what you want to achieve by creating a project or business. Video is a powerful marketing tool for a business. It will not ensure absolute success, but it guarantees the attention of Internet users. Be sure to introduce yourself in the video, tell the background of the project, explain why support is needed, what exactly the money will be spent on, provide information about the stages of the project and rewards (Andriushchenko, Datsii et al., 2019).

8. Description of the project. The project description should be as detailed as possible. Excerpts from the business plan should be included:

- project essence;

- project objectives;

- ways to achieve these goals;

- plans, the main stages of the project;

- costing, justification.

These aspects are described in the paragraph "Creating a video message" and "Defining a financial goal". It is desirable that the description is accompanied by illustrations, photos. A person is disposed to the perception of information in graphical form, as it saves his time, simplifies the process of studying the material.

9. Regular updates. In the process of collecting money, you must constantly improve your offer for the better. People do not want to lose the money they have invested.

It is necessary to maintain contact with people, constantly notify subscribers about the latest developments in attracting investments.

10. Monitoring the fundraising process. To monitor the fundraising process, you should use indicators of structure and dynamics:

1) the share of funds raised in the total amount of the financial goal at time t,\%:

Sum $\mathrm{Si} / \mathrm{S} * 100$

where:

- $\quad$ Si is the amount of funds collected for the i-day;

- $\quad \mathrm{t}$ - settlement day;

- $\quad \mathrm{S}$ - financial purpose.;

2) the share of uncollected funds in the total amount of the financial goal for t, \%:

S- Sum Si/S*100

Here:

$\mathrm{Si}$ is the amount of funds collected for the i-day;

$\mathrm{t}$ - settlement day;

$\mathrm{S}$ - financial purpose.

3) fee growth rate:

Sum Si/(S-1)*100

Here:

- $\quad$ Si is the amount of funds collected for the i-day; 
- $\quad \mathrm{t}$ - settlement day;

- $\mathrm{S}$ - financial purpose..;

Calculation of cost savings when using crowdfunding. Cost savings are determined for the bearer of the project idea. At the same time, different options for funding sources are compared (Andriushchenko, Kovtun. et al. 2020) Self-financing, credit financing, issue financing, state financing, leasing are alternative sources.

Taking risk into account when organizing a crowdfunding campaign. The adoption of managerial decisions related to the financial activities of the enterprise is taken in risk conditions (Polischuk Y., and others. (2018)). In a general sense, risk is the possibility of unfavorable situations and consequences during the implementation of a project. When making decisions, there is a risk of loss of resources: material, labor, information, intellectual and, most importantly, financial.

The following methods are used to assess risk:

- statistical;

- expert;

- building models of random processes.

In this study, a statistical risk assessment method is preferred (Piva, E., Rossi-Lamastra, C. (2018)).

When assessing risk, the following actions will be required:

1) identification of factors affecting the risk, and their analysis;

2) the formulation of possible scenarios of the outcome of events;

3) an assessment of the probability of each of the scenario's emergency;

4) financial risk assessment.

When performing these actions should be guided by the following concepts and provisions of probability theory:

$p(A)$ is the probability of occurrence of event $A$;

$\mathrm{p}(\mathrm{A} 1 \mathrm{~A} 2)=\mathrm{p}(\mathrm{A} 1) \cdot \mathrm{p}(\mathrm{A} 2)$

is the probability of a set of two independent events;

$\mathrm{p}(\mathrm{A})=1-\mathrm{p}(\mathrm{A})$

is the probability of event A not occurring;

When organizing a crowdfunding campaign, the author of the project should take into account the risk associated with the fact that the author may receive a sum less than it is planned to collect on the crowdfunding platform and which will be directed to the implementation of the project. In order to assess this risk, the project author needs to follow the previously described series of sequential actions.

1. Identification of factors affecting the risk, and their analysis

The following factors can be identified as factors affecting the risk associated with the fact that the author may receive less amount than planned: the percentage of the crowdfunding platform commission, the percentage of the payment system collection, personal income tax rate or income tax.

Based on the author's concerns described above, we will develop the following scenarios for the outcome of events: 


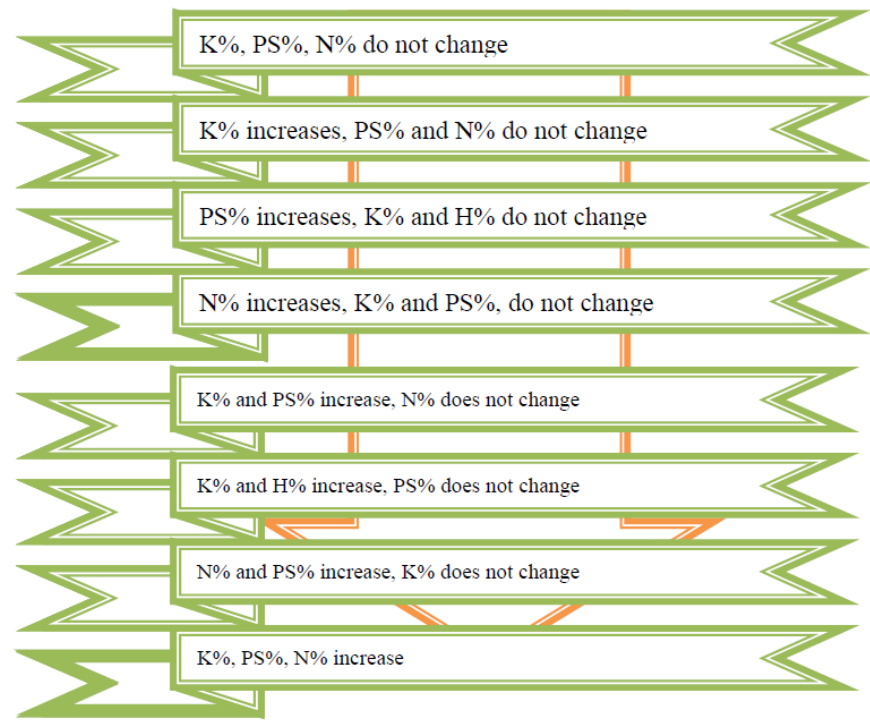

Figure 2. Outcome of events

Source: formed by authors

Suppose the author of the project is afraid of the following events:

- increase in the commission percentage of the crowdfunding platform $\mathrm{K} \%$ from 5 to $10 \%$ (the probability of this event is estimated by the author at $40 \%$ );

- increase the percentage of collection of the payment system PS\% from 5 to $8 \%$ (the probability of this event is estimated by the author at $25 \%$ );

\section{Formulation of possible outcome scenarios}

Based on the author's concerns described above, we will develop the following scenarios for the outcome of events

It is possible to check whether all possible scenarios have been developed using the formula for the number of all possible placements with repetitions of $\mathrm{n}$ elements of $\mathrm{k}$ :

Ank $=\mathrm{nk}$

In this case, the number of options (scenarios) of two elements (event completion and failure) in three (number of events) will be:

$\mathrm{A} 23=8$

Therefore, when checking, the number of various scenarios should be 8 .

3. Assessment of the probability of each of the scenario's emergency. Events are assumed to be independent. Therefore, knowing the probability of occurrence of events separately.

4. Financial risk assessment. As shown in the previous paragraph, the mathematical expectation (average value) can be calculated as a risk indicator. Having estimated the probability of each of the scenarios emergency, it is necessary to calculate the expected results for each scenario. In this case, the result is considered the amount of funds that the author will receive after deductions from the financial goal and direct to the creation and primary functioning of the business.

\section{Results}

We will analyze the viability of crowdfunding as a way of financing using the example of the activities of the largest crowdfunding platform in the world called Kickstarter.com, which began its existence on April 28, 2009 and today is recognized as the most successful. Initially, only US and UK citizens, over 18 years old and having a debit or credit card, could post projects on Kickstarter.com. In 2016, the site expanded its geography, adding the ability to launch projects from Mexico, Hong Kong and Singapore. 


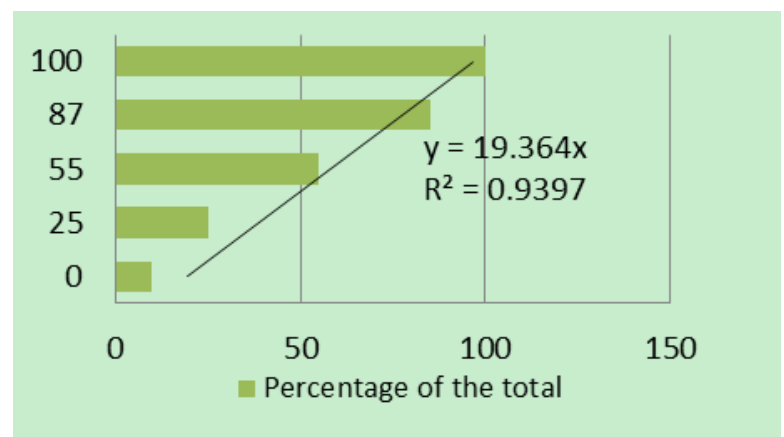

Figure 3. The relationship between the amount of investment and the percentage of the total

Source: formed by authors

According to statistics, users see only about $75 \%$ of projects, since the rest are blocked at the stage of moderation of the application due to non-compliance with Kickstarter rules. The resource earns by deducting a commission of 5\%, plus $3-5 \%$ goes to the payment system. Moreover, the income comes only from fully funded projects that, by the announced day, have collected the necessary amount. In other words, if, for example, the project required $\$ 100,000$ and the maximum collection period was set to 60 days, but only $\$ 40,000$ could be collected, then all the money is returned to investors (the "All or nothing" collection model) and Kickstarter does not earn anything.

The amount of investment can be any. However, in order to increase the average contribution amount, project managers offer users various "gifts". Moreover, the larger the deposit amount, the more interesting and significant the bonus is, from written thanks to a personal meeting and a free version of the product (Kovtun et al., 2020). American analysts Yancy Strickler and Fred Benenson analyzed the platform's activities for 500 days and revealed the relationship between the amount of a one-time donation and a percentage of the amount collected (Fig. 4).

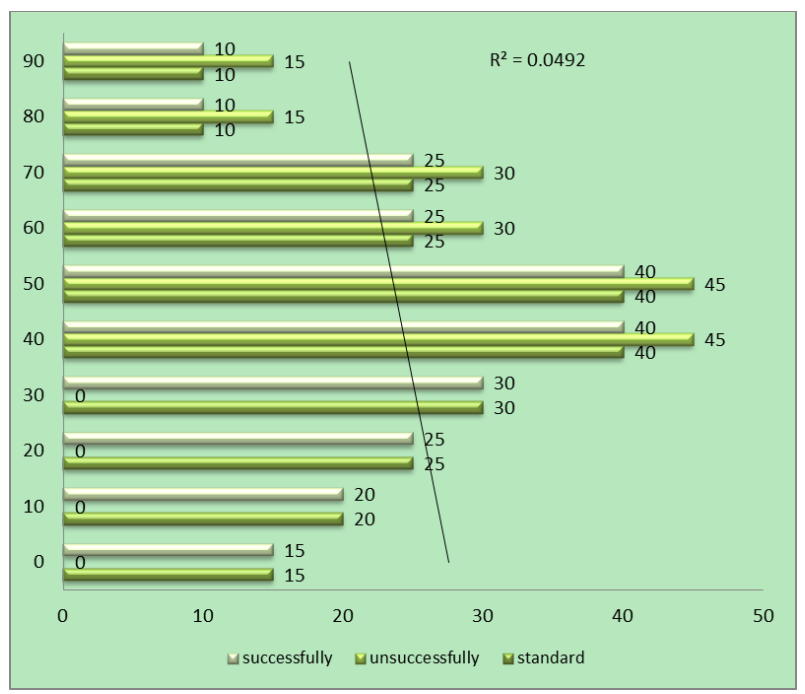

Figure 4. Project duration

Source: formed by authors

In the process of analyzing successful projects, analysts noticed that the amount of remuneration of $\$ 100$ turned out to be dominant, such an amount is invested by an average of $16.36 \%$ of all platform donors, contributions up to $\$ 25$ provide only $10 \%$ of the total donations, but at the same time the largest number of investors is $38 \%$. Their special value is not so much in financing as in the dissemination of information about the project through social networks, communication with friends and acquaintances. In the graph below (Fig. 5), the curves of five successful projects with different durations $(30,35,45,60,90$ days) are plotted. This graph is interesting that all the curves have approximately the same shape. Most of the donations come from the start of the project, followed by a "dead zone" 
with minimal investment, and at the end the last surge occurs. It is necessary to maintain the dynamics of fees, various promotions, advertising and other events, otherwise the project may forever remain in the "dead zone".

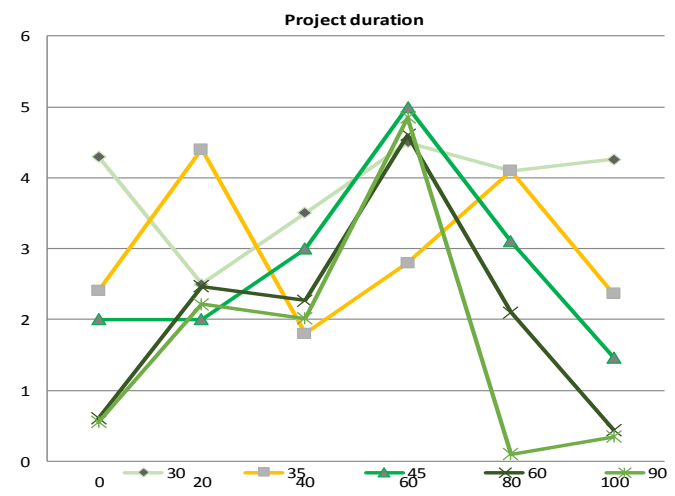

Figure 5. The probability density function of the project and its success

Source: formed by authors

To date, Kickstarter has a total of 15 sections into which all proposed projects can be divided (Table 1). Our study showed that users are most interested in creative projects related to recording an album, making a film or developing a game, as well as technological orientation.

Table 1. The success of projects in different categories

\begin{tabular}{llll}
\hline Category & Total projects & The share of successful projects, $\%$ & Donated, \$ US \\
\hline Art & 29869 & 41,26 & 95477939 \\
\hline Comics & 11720 & 55,28 & 7824223 \\
\hline Dancing & 3909 & 61,96 & 13473304 \\
\hline Design & 32074 & 35,60 & 783124041 \\
\hline Fashion & 24449 & 25,2 & 147317799 \\
\hline Movies andvideos & 67038 & 37,5 & 407951876 \\
\hline Food & 25791 & 24,93 & 132117486 \\
\hline Games & 38049 & 36,41 & 823144565 \\
\hline Music & 55930 & 49,50 & 214953600 \\
\hline The photo & 11175 & 30,82 & 40283635 \\
\hline Publications & 41952 & 1,666 & 139911251 \\
\hline Technology & 34572 & 19,99 & 729003932 \\
\hline Theater & 11169 & 59,78 & 41084968 \\
\hline Handicrafts & 9313 & 24,01 & 15484968 \\
\hline Journalism & 4995 & 21,72 & 13484968 \\
\hline
\end{tabular}

Source: formed by authors

Researchers also traced the link between success and project lifetime. It turns out that projects with the shortest declared duration are more likely to succeed (Figure 6). Ironically, they found that 30-day projects are usually 
created by people who are more optimistic about their chances and who continue to engage new supporters to their project.

Conversely, people who choose a longer term are less confident in their work and it is more difficult for them to maintain excitement over such a period. Researchers recommend a 30-day project duration, because even 30 days for the Internet is too long.

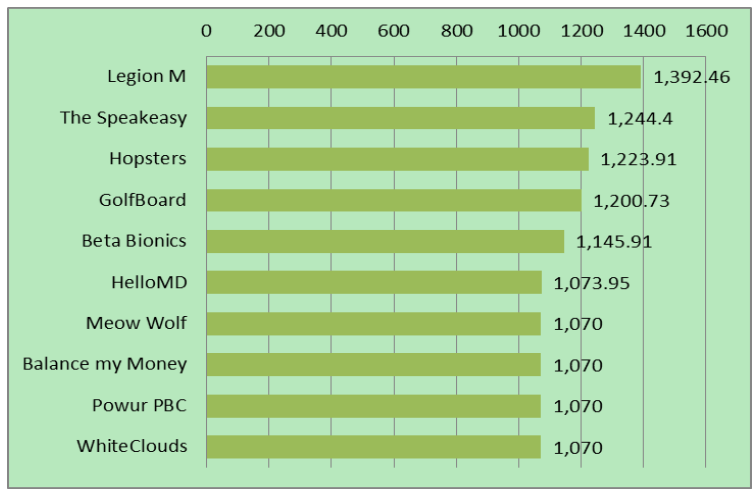

Figure 6. Leading regulation crowdfunding campaigns in the United States as of September 2017, by amount of money raised (in thousand U.S. dollars)

Source: formed by authors

On average, the share of successful projects is $36.1 \%$. The platform is developing rapidly and by April 2018 has collected a total of more than $\$ 3.6$ billion in investments from 14,608,578 people from 224 countries, Russia accounts for about $1.5 \%$ of total fees, and the United States accounts for more than half of all fees. The dynamics of the general fees is presented in the figure below.

\section{Discussion}

The Cambridge Center for Alternative Finance (CCAF) has been studying alternative finance and collecting crowdfunding market data since 2015 as it provides a larger data set and includes more funding models such as donation and award-based crowdfunding.

The latest published publications relate to 2019 presented below. The table shows the 30 countries with the largest market share in crowdfunding, including the total crowdfunding in the world. Figures from the Cambridge Center for Alternative Finance show that the total global crowdfunding market in 2018 amounted to $\$ 416.67$ billion compared to $\$ 288.99$ billion in 2017 .

China is the world's largest crowdfunding market.

With a market size of $\$ 358.28$ billion and a share of $85.99 \%$, China is the largest crowdfunding market in the world. The development of crowdfunding in China did not begin until 2013, and the impressive growth rate leading to the status of the largest market in the world did not go without consequences. Since the end of 2015, several crowdfunding platforms have been recognized as fraudsters, and many others have been forced to close due to liquidity problems. Others are again abandoning P2P lending and other forms of crowdfunding to focus on more traditional markets, such as the retail investment market (Liezina et al., 2020).

The Chinese authorities are still in the process of introducing stricter regulation in relation to crowdfunding platforms with a special emphasis on P2P lending, which will definitely negatively affect the market - at least in the short term. However, there is a very real demand for crowdfunding in China, and crowdfunding financing still makes up only a small part of the overall borrowing market, leaving enough room for further growth after many regulatory initiatives.

The projected amount of the transaction in the crowdfunding segment in 2020 amounted to $\$ 7,048.9$ million. The transaction value is expected to have an annual growth rate (CAGR 2020-2023) of 13.1\%, resulting in a total of $\$ 10,208.3$ million by 2023 . The average funding per campaign in the crowdfunding segment in 2020 is $\$ 665$. In terms of global comparison, it is shown that the highest transaction value was achieved in China $(\$ 7,049$ million in 2020). 


\section{Asian-Pacific area}

Due to the fact that Australia took 4th place with funding of \$ 1.49 billion. USA, and South Korea - 5th place with $\$ 1.13$ billion. We also find other countries in the Asia-Pacific region in the list of the largest crowdfunding countries in the world. Japan is also in the top 10, and further in the list, we have India (\# 12), New Zealand (\# 13), Singapore (\# 17), Chinese Taipei (\# 24) and Indonesia (\# 28).

Region of the USA and America

Just like China in the Asia-Pacific region, the United States absolutely dominates the region of the Americas, where their market share is $96.5 \%$. With a global market share of $10.27 \%$ and funding of $\$ 42.8$ billion, they are also China's only real competitor when they look at global data. From the countries of North and South America, especially Canada, it can be an interesting example in subsequent years, since it has already taken 6th place in the list with the volume of financing of $\$ 0.87$ billion. At the same time, the United States is showing high growth rates (159.4\% in 2017). Further down the list, we find three Latin American countries - Brazil (\# 11), Mexico (\# 20) and Chile (\# 21) - which will also be interesting in the coming years, since steady growth is observed in Latin America and the Caribbean.

\section{Great Britain and Europe}

Despite the fact that in Europe there are many players in crowdfunding, especially in the field of $\mathrm{P} 2 \mathrm{P}$ lending, in comparison with the Americas and the Asia-Pacific region, in general this is a small region. Nevertheless, the UK confidently ranks third in the world with a market share of $1.88 \%$ and funding of $\$ 7.85$ billion and is one of the most famous crowdfunding markets in the world.

Other large markets for crowdfunding in Europe are France, which took 7th place, and Germany, which took 8th place with funding volumes of $\$ 0.73$ billion and $\$ 0.66$ billion, respectively. Europe is widely represented in the top 30, but the region includes countries with less funding. Other European countries represented in the top 30 are: the Netherlands (\# 10), Italy (\# 14), Finland (\# 15), Sweden (\# 16), Spain (\# 19), Poland (\# 22), Ireland (\# 23), Latvia (\# 25),

\section{Conclusions}

The modern practice of investing, like all phenomena of the socio-economic life of society, is developing under the influence of the Internet. In recent years, a funding tool such as crowdfunding has become widespread in the world. The dynamic development of crowdfunding is due to the fact that crowdfunding provides the entrepreneur with simultaneous access to a wide range of potential investors and is characterized by a relative, in comparison with other investment instruments, low cost of raising capital.

With important signs of crowdfunding as a business model is socialization of a specific process, you can protect yourself without interruption by readers and viewers, as well as realizing digital platforms. Although today the crowdfunding market is only making the first steps towards its development, its prospects are enormous. It reaches an online audience of 15 million users, who spend an average of 20 hours a week online. People's confidence in various venues is gradually increasing (this can be seen from the example of online auctions). So, the volume of cash flow from the private population - to the initiators of various projects and startups will increase.

\section{References}

Andriushchenko, K., Buriachenko, A., Rozhko, O., Lavruk, O., Skok, P., Hlushchenko, Y., ... Kondarevych, V. (2020). Peculiarities of sustainable development of enterprises in the context of digital transformation. Entrepreneurship and Sustainability Issues, 7(3), 2255-2270. http://doi.org/10.9770/jesi.2020.7.3(53)

Andriushchenko, K., Datsii, O., Aleinikova, O. A., Mohamed, A., \& Mohammed, A. A. (2019). Improvement of the water resources management system at the territorial level. Problems and Perspectives in Management, (17), 421-437. https://doi.org/10.21511.34

Andriushchenko, K., Kovtun, V., Shergina, L., Rozhko, O., \& Yefimenko, L. (2020). Agro-based clusters: a tool for effective management of regional development in the era of globalisation. TEM Journal, 9(1), 198-204. https://doi.org/10.18421/TEM91-28

Andriushchenko, K., Tepliuk, M., Boniar, S., Ushenko, N., \& Liezina, A. (2019). Influence of cost drivers on value-oriented management of investment activity of companies. Investment Management and Financial Innovations, 16, 353-364. https://doi.org/10.21511/imfi.16(3).2019.31 
Baeck, P., Collins, L., \& Zhang, B. (2014). Understanding alternative finance: The UK alternative finance industry report 2014. National Endowment for Science Technology \& Arts, NESTA. Retrieved from https://media.nesta.org.uk/documents/understanding-alternative-finance-2014.pdf

Bapna, S. (2017). Complementarity of signals in early-stage equity investment decisions: Evidence from a randomized field experiment. Management Science.

Bretschneider, U., Knaub, K., \& Wieck, E. (2014). Motivations for crowdfunding: What drives the crowd to invest in start-ups?. Proceedings of the European Conference on Information Systems (ECIS) 2014, Tel Aviv, Israel. Retrieved from http://aisel.aisnet.org/ecis2014/proceedings/track05/6

Brown, R., Mawson, S., \& Rowe, A. (2018). Start-ups, entrepreneurial networks and equity crowdfunding: A processual perspective. Industrial Marketing Management, Forthcoming.

Cholakova, M., \& Clarysse, B. (2015). Does the possibility to make equity investments in crowdfunding projects crowd out rewards-based investments?. Entrepreneurship Theory and Practice, 39(1), 145-172.

Drover, W., Busenitz, L., Matusik, S., Townsend, D., Anglin, A., \& Dushnitsky, G. (2017). A review and road map of entrepreneurial equity financing research: Venture capital, corporate venture capital, angel investment, crowdfunding, and accelerators. Journal of Management, 43(6), 1820-1853.

Estrin, S., Daniel Gozman, D., \& Khavul, S. (2018). The evolution and adoption of equity crowdfunding: Entrepreneur and investor entry into a new market. Small Business Economics, 51, 425-439.

Guenther, C., Hienerth, C., \& Riar, F. (2014). The due diligence of crowdinvestors: Thorough evaluation or gut feeling only?. Presented at the 12th International Open and User Innovation Conference. Retrieved from http://userinnovation.mit.edu/conf2014/

Guenther, C., Johan, S., \& Schweizer, D. (2018). Is the crowd sensitive to distance? How investment decisions differ by investor type. Small Business Economics, 50, 289-305.

Hornuf, L., \& Schwienbacher, A. (2016). Crowdinvesting: Angel investing for the masses?. In H. L. C. Mason (Ed.), Handbook of Research on Business Angels (pp. 381-397). Cheltenham: Edward Elgar.

Horvát, E.-Á., Wachs, J., Wang, R., \& Hannák, A. (2018). The role of novelty in securing investors for equity crowdfunding campaigns. Presented at the 6th AAAI Conference on Human Computationand Crowdsourcing (HCOMP 2018), Zurich, Switzerland.

Kim, K., \& Viswanathan, S. (2018). The "experts" in the crowd: The role of experienced investors in a crowdfunding market. Retrieved from https://ssrn.com/abstract=2765488

Kovtun, V., Andriushchenko, K., Horbova, N., Lavruk, O., \& Muzychka, Y. (2020). Features of the Management Process ofAmbidextrous Companies. TEM Journal, 9(1), 221-226. https://doi.org/10.18421/TEM91-31

Liezina, A., Andriushchenko, K., Rozhko, O., Datsii, O., Mishchenko, L., \& Cherniaieva, O. (2020). Resource planning for risk diversification in the formation of a digital twin enterprise. Accounting, 6, 1337-1344. https://doi.org/10.5267/j.ac.2020.8.016

Löher, J., Schneck, S., \& Werner, A. (2018). A research note on entrepreneurs' financial commitment and crowdfunding success. Venture Capital, 20(3), 309-322.

Lukkarinen, A., Teich, J. E., Wallenius, H., \& Wallenius, J. (2016). Success drivers of online equity crowdfunding campaigns. Decision Support Systems, 87, 26-38.

Martínez-Climent, C., Zorio-Grima, A., \& Ribeiro-Soriano, D. (2018). Financial return crowdfunding: Literature review and bibliometric analysis. International Entrepreneurship and Management Journal, 14(3), 527-553.

Mochkabadi, K., \& Volkmann, C. K. (2018). Equity crowdfunding: A systematic review of the literature. Small Business Economics.

Piva, E., \& Rossi-Lamastra, C. (2018). Human capital signals and entrepreneurs' success in equity crowdfunding. Small Business Economics, 51, 667-686.

Polischuk, Y., Sybirianska, Y, \& Ivashchenko, A. (2018). Fintech-platforms in SME's financing: EU experience and ways of its applicability in Ukraine. Investment Management and Financial Innovations, 3, 83-96.

Tuomi, K., \& Harrison, R. T. (2017). A comparison of equity crowdfunding in four countries: Implications for business angels. Strategic Change, 26(6), 609-615. 
Venturelli, V., Pedrazzoli, A., \& Gualandri, E. (2018). Birds of a feather flock together and get money from the crowd. Presented at the 3rd Entrepreneurial Finance Conference (ENTFIN2018), Milan, Italy.

Vismara, S. (2016). Equity retention and social network theory in equity crowdfunding. Small Business Economics, 46, 579-590.

Vulkan, N., Åstebro, T., \& Sierra, M. F. (2016) Equity crowdfunding: A new phenomena. Journal of Business Venturing Insights, 5, 37-49.

Wright, M., Hart, M., \& Fu, K. (2015). A nation of angels: Assessing the impact of angel investing across the UK. Enterprise Research Centre $\quad$ Retrieved from https://www.enterpriseresearch.ac.uk/wpcontent/uploads/2015/01/ERC-Angels-Report.pdf

\section{Copyrights}

Copyright for this article is retained by the author(s), with first publication rights granted to the journal.

This is an open-access article distributed under the terms and conditions of the Creative Commons Attribution license (http://creativecommons.org/licenses/by/4.0/). 